\title{
HUBUNGAN RASA PERCAYA DIRI DAN KEBIASAAN BELAJAR TERHADAP HASIL BELAJAR MATEMATIKA SISWA KELAS IX SMP NEGERI 16 BATAM TAHUN PELAJARAN 2016/2017
}

\author{
Gustina Ningsih ${ }^{1}$, Riska Novia Sari ${ }^{2}$ \\ Program Studi Pendidikan Matematika, Fakultas Keguruan dan Ilmu Pendidikan, \\ Universitas Riau Kepulauan, Batam \\ e-mail: gustinan@ rocketmail.com, riskanovia30@gmail.com
}

\begin{abstract}
Abstrak. Penelitian ini bertujuan untuk mengetahui apakah terdapat hubungan antara rasa percaya diri dan kebiasaan belajar dengan hasil belajar matematika siswa kelas IX SMPN N 16 Batam. Jenis penelitian ini yaitu penelitian korelasional dengan populasi sebanyak 355 orang. Dalam penelitian ini sampel yang digunakan adalah kelas IX SMP N 16 Batam sebanyak 189 siswa. Instrumen yang digunakan berupa angket rasa percaya diri dan kebiasaan belajar yang telah diuji validitas dan reliabilitasnya. Teknik analisa yang digunakan dalam penelitian ini untuk menguji hipotesisnya dengan menggunakan rumus korelasi parsial dan korelasi berganda yang dilakukan dengan bantuan software SPSS versi 20. Hasil penelitian ini menunjukkan bahwa terdapat hubungan yang positif dan signifikan antara rasa percaya diri dan kebiasaan belajar terhadap hasil belajar matematika siswa kelas IX SMP N 16 Batam. Dengan besar korelasi $=0,815$ yaitu pada kategori sangat kuat, arah hubungan positif karena nilai $\mathrm{R}$ positif dan memperoleh signifikansi $0,00<0,05$. Artinya adalah semakin tinggi rasa percaya diri dan kebiasaan belajar siswa maka akan semakin tinggi pula hasil belajar matematika yang dicapai oleh siswa tersebut dan begitu juga sebaliknya.

Kata kunci: rasa percaya diri, kebiasaan belajar, dan hasil belajar matematika.
\end{abstract}

\begin{abstract}
The purpose of the research was to figure out the correlation between students' selfconfidence and learning habit with their mathematics learning outcames. The type of this research was correlational in which the population consisted of 355 students. The sample of the research was student of grade IX consisting of 189 students. The instrument used in the research was selfconfidence and learning habit questionnaire which had been tested for its validity and reliability. Technique of analysis used in testing the hypothesis was partial and multiple correlational formula done by using software SPSS verse 20. The result of the research shows that there is a positive and significant correlation between self-confidence and learning habit with students, mathematics learning outcames. The correlation was 0,815 which was in very strong category, and it was a positive correlation because the value of $\mathrm{R}$ was positive and it got significance of $0,00<0,05$. It means the higher self-confidence and learning habit students' have, it will be the higher their mathematics learning outcames will be.

Key words: Self Confidence, Laerning Habit, Mathematics Learning Outcome
\end{abstract}

\section{PENDAHULUAN}

Pendidikan merupakan gerbang utama untuk kemajuan suatu bangsa dan negara. Proses pendidikan sangat berkaitan dengan kegiatan belajar mengajar. Kegiatan belajar mengajar merupakan suatu alat yang sangat penting untuk membantu siswa dalam meningkatkan kemampuan melalui berbagai aktivitas belajar. Adapun proses belajar belajar mengajar berkaitan dengan interaksi antara guru dan siswa dalam melaksanakan pembelajaran. Salah satu materi pembelajaran yang harus dikuasai oleh siswa di sekolah adalah matematika. Thurston (dalam Turmudi 2009: 1) mengibaratkan matematika sebagai pohon banyan yang tumbuh subur di hutan yang akan memacu kita untuk memanjat serta mengeksplorasinya, maksudnya adalah kemampuan siswa dalam matematika akan bertambah atau semakin mendalam apabila siswa memiliki kesempatan untuk mempelajari matematika lebih mendalam. 
Faktanya di lapangan masih banyak siswa yang tidak memanfaatkan kesempatan untuk mengolah kemampuan matematikanya. Permasalahan-permasalahan terkait pembelajaran matematika diakibatkan oleh banyak faktor, diantaranya yaitu faktor internal. Rasa percaya diri merupakan salah satu faktor internal dalam belajar. Percaya diri terbina dari keyakinan diri sendiri, sehingga kita mampu menghadapi tantangan hidup apapun dengan berbuat sesuatu. Menurut Aunurrahman (2014: 184) rasa percaya diri umumnya muncul ketika seseorang akan melakukan atau terlibat didalam suatu aktivitas tertentu dimana pikirannya terarah untuk mencapai sesuatu hasil yang diinginkannya. Rasa percaya diri dapat muncul dalam diri seseorang apabila memiliki keinginan untuk melakukan apapun, sampai tujuan yang diinginkannya tercapai. Rasa percaya diri bukan merupakan bakat atau bawaan melainkan kualitas mental, artinya rasa percaya diri merupakan pencapaian yang dihasilkan dari proses pendidikan.

Berdasarkan hasil observasi saat melaksanakan PPL di kelas VIII SMP Negeri 16 Batam, terlihat bahwa beberapa siswa yang masih merasa takut, ragu-ragu dan malu jika gurunya meminta untuk maju menyelesaikan suatu persoalan matematika di depan kelas. Siswa cenderung merasa tidak mampu untuk mengerjakan soal sehingga mereka pun menolak untuk maju ke depan kelas dan membiarkan siswa yang lebih mampu agar menyelesaikan persoalan matematika tersebut. Selain itu, siswa selalu mudah menyerah atau bersifat pesimis saat tidak mampu menyelesaikan permasalahan matematika yang dianggap sulit sehingga siswa lebih cenderung percaya dengan hasil pekerjaan temannya. berdasarkan permasalahan di atas dapat disimpulkan bahwa rasa percaya diri siswa kelas VIII SMP Negeri 16 Batam masih rendah.

Faktor internal lainnya yang dapat mempengaruhi hasil belajar matematika siswa adalah kebiasaan belajar. Kebiasaan belajar merupakan sutau perilaku belajar seseorang yang tertanam dalam waktu yang relatif lama sehingga memberikan ciri dalam kegiatan belajar yang dilakukannya. Selain itu, Djaali (2014: 127) mengartikan "kebiasaan belajar sebagai cara atau teknik yang menetap pada diri siswa pada waktu menerima pelajaran, membaca buku, mengerjakan tugas dan pengaturan waktu untuk menyelesaikan kegiatan”. Kebiasaan belajar yang kurang baik dapat terlihat saat terjadinya proses pembelajaran. Kebiasaan belajar yang kurang baik ini seperti: belajar tidak teratur, belajar saat ada tugas maupun ulangan dan ujian, tidak memiliki catatan lengkap, serta suka melihat atau menyontek pekerjaan temannya. Beberapa hal tersebut menandai adanya kebiasaan belajar yang kurang baik dan biasanya sebagian besar siswa melakukan hal tersebut.

Kebiasaan belajar yang belum baik pada siswa diduga dapat menimbulkan dampak yang tidak baik pula bagi diri siswa itu sendiri. Akibat yang dapat ditimbulkan lainnya adalah tidak dapat tercapainya hasil belajar yang diinginkan. Hal ini dikarenakan kebiasaan belajar berkaitan dengan perilaku yang dilakukan siswa sehari-hari. Dengan adanya kebiasaan belajar yang baik diduga bisa memberi peran yang cukup penting dalam pencapaian suatu hasil belajar yang lebih baik. Maka dari itu perlu adanya perubahan kearah yang lebih baik terhadap kebiasaan belajar siswa, sehingga siswa dapat memperoleh hasil belajar yang baik pula.

Nana (2012: 22) mengartikan "hasil belajar adalah kemampuan-kemampuan yang dimiliki siswa setelah siswa menerima pengalaman belajarnya". Untuk dapat mencapai hasil 
belajar yang baik, diperlukan usaha yang tinggi dalam mencapainya. Berdasarkan data yang diperoleh dari SMP N 16 Batam, terlihat hasil belajar matematika siswa masih banyak yang belum mencapai Kriteria Ketuntasan Minimal (KKM). Rendahnya hasil belajar siswa diduga diakibatkan oleh rendahnya rasa percaya diri dan kebiasaan belajar siswa. Untuk membuktikan hal tersebut dilakukan penelitian ini yang bertujuan untuk mengetahui: 1) hubungan antara rasa percaya diri terhadap hasil belajar matematika siswa kelas IX di SMP Negeri 16 Batam Tahun Pelajaran 2016/2017; 2) hubungan antara kebiasaan belajar terhadap hasil belajar matematika siswa kelas IX di SMP Negeri 16 Batam Tahun Pelajaran 2016/2017; dan 3) hubungan antara rasa percaya diri dan kebiasaan belajar secara bersama-sama terhadap hasil belajar matematika siswa kelas IX di SMP Negeri 16 Batam Tahun Pelajaran 2016/2017.

\section{METODE PENELITIAN}

Jenis penelitian yang digunakan yaitu penelitian korelasional. Menurut Sugiyono (2013:260) analisis korelasi digunakan untuk mencari arah dan kuatnya hubungan antara dua variabel atau lebih, baik hubungan yang bersifat simetris, kausal dan reciprocal seluruh siswa kelas IX SMP Negeri 16 Batam Tahun Pelajaran 2016/2017 yang terdiri atas 7 kelas dan berjumlah 355 orang siswa. Adapun teknik sampling yang akan digunakan pada penelitian ini adalah simpel random sampling dengan rumus Slovin (Siregar, 2015: 61) sehingga diperoleh banyak sampel 189 siswa. Variabel bebas dalam penelitian ini yaitu rasa percaya diri dan kebiasaan belajar, sedangkan variabel terikatnya adalah hasil belajar matematika siswa.

Instrumen untuk mengumpulkan data pada penelitian ini disusun dalam bentuk angket/kuisioner rasa percaya diri dan kebiasaan belajar. Angket berisi sejumlah pertanyaanpertanyaan yang harus dijawab oleh responden penelitian. Angket terdiri dari dua bagian yakni bagian pertama merupakan bagian pendahuluan yang berisi pengisian yang berkaitan dengan identitas diri responden dan tata cara atau petunjuk pengisian angket. Sedangkan bagian yang kedua merupakan bagian isi yang berisi hal-hal yang harus diisi oleh responden baik hal yang bersifat positif maupun hal yang bersifat negatif. Angket dibuat dan dikembangkan sesuai dengan indikator-indikator yang telah ditentukan. Adapun indikator rasa percaya diri yang digunakan dalam penelitian ini yaitu : 1) optimis; 2) kemampuan menghadapi masalah; 3) mandiri; 4) bertanggung jawab terhadap keputusan dan tindakannya. Sedangkan indikator kebiasaan belajar yaitu, 1) persiapan belajar; 2) cara mengikuti pelajaran; 3) cara belajar kelompok; 4) cara belajar individu; 5) membuat jadwal dan pelaksanaanya ; 6) membaca dan membuat catatan; 7) mengulang bahan pelajaran; 8) waktu belajar.

Angket yang digunakan dalam penelitian ini menggunakan skala likert yang terdiri dari 4 pilihan jawaban. Adapun skala likert yang digunakan untuk variabel rasa percaya diri yaitu Sangat Setuju (ST), Setuju (S), Tidak Setuju (TS) dan Sangat Tidak Setuju (STS). Sedangkan untuk variabel kebiasaan belajar yaitu Tidak Pernah, Kadang-kadang, Sering, dan Selalu.

Sebelum angket digunakan dalam penelitian, dilakukan terlebih dahulu uji coba yaitu angket diujikan kepada siswa di luar sampel. Dari hasil uji coba tersebut kemudian dilakukan uji validitas dan reliabilitas. Siregar (2015: 75) menyatakan bahwa validitas atau kesahihan menunjukkan sejauh mana suatu alat ukur mampu mengukur apa yang ingin diukur. Uji 
validitas yang digunakan dalam penelitian ini adalah validitas konstruk. Berdasarkan perhitungan uji validitas pertama, untuk angket rasa percaya diri yang terdiri dari 24 butir pernyataan, maka terdapat 19 pernyataan yang valid dan 5 pernyataan yang tidak valid. Dari 19 pernyataan yang valid, dilanjutkan uji validitas kedua dan diperoleh semuanya valid. Selanjutnya perhitungan uji validitas pertama untuk angket kebiasaan belajar yang terdiri dari 24 butir pernyataan, maka terdapat 17 pernyataan yang valid dan 7 pernyataan yang tidak valid. Dari 17 pernyataan yang valid dilanjutkan uji validitas kedua dan diperoleh semuanya valid. Sehingga dalam penelitian ini digunakan 19 pernyataan angket rasa percaya diri dan 17 pernyataan angket kebiasaan belajar. Uji reliabilitas yang digunakan pada penelitian ini menggunakan rumus Alpha Cronbach. Pernyataan dinyatakan reliable apabila koefisien

reliabilitas >0,6. Berdasarkan pengujian reliabilitas angket rasa percaya diri dan kebiasaan belajar diperoleh $r_{11}=0,872$ dan $r_{11}=0,780$ yang artinya nilai kedua $\quad 0,6$ dan kedua instrument tersebut reliabel.

Uji prasyarat analisis dilakukan sebelum melakukan uji hipotesis yaitu uji normalitas. Uji normalitas pada penelitian ini menggunakan metode Kolmogorov-Smirnov menggunakan bantuan software SPSS versi 20. Adapun kaidah pengujiannya jika probalitas (sig.) 0,05 maka data berdistribusi normal dan sebaliknya. Selanjutnya untuk menjawab hipotesis 1 dan 2 yaitu hubungan dari masing-masing variabel bebas terhadap variabel terikatnya dilakukan uji korelasi parsial dan untuk hipotesis 3 yaitu mengetahui hubungan dari kedua variabel bebas secara bersama-sama terhadap variabel terikatnya digunakan uji korelasi berganda. Selanjutnya dihitung Koefisian Determinasi (KD) yang berfungsi untuk mengetahui seberapa besar sumbangan yang diberikan oleh variabel bebas kepada variabel terikat.

\section{HASIL PENELITIAN DAN PEMBAHASAN}

Angket rasa percaya diri dan kebiasaan belajar yang masing-masing berjumlah 19 pernyataan dan 17 pernyataan dibagikan kepada 189 siswa dan diperoleh deskripsi data sebagai berikut:

Tabel 1. Deskripsi Data

\begin{tabular}{ccc}
\hline & Rasa Percaya Diri & Kebiasaan Belajar \\
\hline$N$ & 189 & 189 \\
\hline Mean & 51,02 & 51,43 \\
\hline Std.Deviation & 4,864 & 4,647 \\
\hline Minimum & 36 & 38 \\
\hline Maximum & 65 & 62 \\
\hline Min ideal & 0 & 0 \\
\hline Max ideal & 76 & 68 \\
\hline
\end{tabular}

Selanjutnya, uji normalitas dengan menggunakan metode Kolmogorov-Smirnov diperoleh hasil sebagai beriku:

Tabel 2. Hasil Perhitungan Uji Normalitas

\begin{tabular}{lcccc}
\hline \multirow{2}{*}{ Variabel } & \multicolumn{3}{c}{ Kolmogorov-Smirnov $^{a}$} & Kesimpulan \\
\cline { 2 - 5 } & Statistic & Df & Sig. & \\
\hline Rasa Percaya Diri & .064 & 189 & .056 & Normal \\
\hline Kebiasaan Belajar & .064 & 189 & .060 & Normal \\
\hline Hasil Belajar Siswa & .055 & 189 & .200 & Normal \\
\hline
\end{tabular}


Data dikatakan normal jika probabilitas (sig) > 0,05. Dari tabel di atas dapat dilihat bahwa, dan Y masing-masing berdistribusi normal.

Pada uji hipotesis 1 menggunakan korelasi sederhana. Uji hipotesis pertama dilakukan untuk mengetahui hubungan rasa percaya diri dengan hasil belajar siswa kelas IX SMP Negeri 16 Batam Tahun pelajaran 2016/2017. Hasil pengujian yang diperoleh sebagai berikut:

Tabel 3. Hasil Perhitungan Hipotesis 1

\begin{tabular}{rlrr}
\hline & & X1 & \multicolumn{1}{c}{$\mathrm{Y}$} \\
\hline \multirow{3}{*}{ X1 } & Pearson Correlation & 1 & $.523^{* *}$ \\
& Sig. (2-tailed) & & .000 \\
& $\mathrm{~N}$ & 136 & 189 \\
\hline \multirow{3}{*}{$\mathrm{Y}$} & Pearson Correlation &, $523^{* *}$ & 1 \\
& Sig. (2-tailed) & .000 & \\
& $\mathrm{~N}$ & 189 & 136 \\
\hline
\end{tabular}

Berdasarkan tabel 3 dapat dianalisis bahwa untuk nilai $=0,523$. Besar hubungan termasuk dalam kategori cukup kuat, yaitu rasa percaya diri memiliki hubungan yang cukup kuat dengan hasil belajar matematika. Sedangkan arah hubungan adalah positif karena nilai $r$ positif, yang artinya semakin tinggi rasa percaya diri yang dimiliki oleh siswa maka semakin tinggi pula hasil belajarnya. Kemudian berdasarkan perhitungan di atas diperoleh uji signifikan sig $=0,000<=0,05$, sehingga keputusannya Ho ditolak. Artinya terdapat hubungan yang positif dan signifikan antara rasa percaya diri dengan hasil belajar matematika siswa kelas VIII SMP Negeri 16 Batam Tahun Pelajaran 2016/2017. Selanjutnya untuk mengetahui besar kecilnya sumbangan yang diberikan oleh variavel $\mathrm{X}_{1}$ terhadap variabel $\mathrm{Y}$ dapat dilihat dari perhitungan berikut:

Artinya besar sumbangan rasa percaya diri terhadap hasil belajar matematika siswa kelas IX SMP Negeri 16 Batam sebesar 27,35\%. Sisanya 72,35\% ditentukan oleh faktor lain yang tidak diteliti dalam penelitian ini.

Pada uji hipotesis 2 menggunakan korelasi sederhana. Uji hipotesis kedua dilakukan untuk mengetahui hubungan kebiasaan belajar dengan hasil belajar siswa kelas IX SMP Negeri 16 Batam Tahun pelajaran 2016/2017. Diperoleh hasil sebagai berikut:

Tabel 4. Hasil perhitungan Hipotesis 2

\begin{tabular}{rlrr}
\hline & & X2 & \multicolumn{1}{c}{ Y } \\
\hline \multirow{3}{*}{ X2 } & Pearson Correlation & 1 & $.780^{* *}$ \\
& Sig. (2-tailed) & & .000 \\
& N & 136 & 189 \\
\hline \multirow{3}{*}{ Y } & Pearson Correlation &, $780^{* *}$ & 1 \\
& Sig. (2-tailed) & .000 & \\
& N & 189 & 136 \\
\hline
\end{tabular}

Berdasarkan tabel 4, nilai adalah 0,780. Besar hubungan termasuk dalam kategori kuat, yaitu kebiasaan belajar memiliki hubungan yang kuat dengan hasil belajar matematika. Sedangkan arah hubungan adalah positif karena nilai $r$ positif, yang artinya semakin tinggi kebiasaan belajar yang dimiliki oleh siswa maka semakin tinggi pula hasil 
belajarnya. Kemudian berdasarkan perhitungan di atas diperoleh uji signifikan sig $=0,000<$ $=0,05$, sehingga keputusannya Ho ditolak. Artinya terdapat hubungan yang positif dan signifikan antara kebiasaan belajar dengan hasil belajar matematika siswa kelas VIII SMP Negeri 16 Batam Tahun Pelajaran 2016/2017.

Sedangkan untuk mengetahui besar kecilnya sumbangan yang diberikan oleh variabel $\mathrm{X}_{2}$ terhadap variabel $\mathrm{Y}$ dapat dilihat dari perhitungan berikut:

Artinya besar sumbangan kebiasaan belajar terhadap hasil belajar matematika siswa kelas IX SMP Negeri 16 Batam sebesar 14,04\%. Sisanya 85,96\% ditentukan oleh faktor lain yang tidak diteliti dalam penelitian ini.

Selanjutnya, uji hipotesis 3 dilakukan untuk mengetahui adanya hubungan antara rasa percaya diri dan kebiasaan belajar dengan hasil belajar siswa secara bersama-sama. Hasil yang diperoleh sebagai berikut:

Tabel 5. Hasil Perhitungan Hipotesis 3

\begin{tabular}{|c|c|c|c|c|c|c|c|c|}
\hline \multirow[t]{2}{*}{ Model } & \multirow[t]{2}{*}{$\mathrm{R}$} & \multirow{2}{*}{$\begin{array}{c}\mathrm{R} \\
\text { Square }\end{array}$} & \multirow{2}{*}{$\begin{array}{l}\text { Adjusted R } \\
\text { Square }\end{array}$} & \multirow{2}{*}{$\begin{array}{l}\text { Std. Error of } \\
\text { the Estimate }\end{array}$} & \multicolumn{4}{|c|}{ Change Statistics } \\
\hline & & & & & $\begin{array}{l}\text { R Square } \\
\text { Change }\end{array}$ & $\begin{array}{c}\mathrm{F} \\
\text { Change }\end{array}$ & $\mathrm{df} 1 \mathrm{df} 2$ & $\begin{array}{l}\text { Sig. F } \\
\text { Change }\end{array}$ \\
\hline 1 & $.815^{\mathrm{a}}$ & .664 & .661 & 7.064 & .664 & 183.975 & 2186 & .000 \\
\hline $\begin{array}{l}\text { a. Pred } \\
\text { b. Dep }\end{array}$ & $\begin{array}{l}\text { ors: }(C \\
\text { dent } V\end{array}$ & $\begin{array}{l}\text { onstant) } \\
\text { ariable: }\end{array}$ & $K_{2}, X_{1}$ & & & & & \\
\hline
\end{tabular}

Berdasarkan tabel 5, dapat dianalisa bahwa untuk ketiga variabel memperoleh nilai sebesar 0,815 menunjukkan bahwa hubungan antara rasa percaya diri dan kebiasaan belajar dengan hasil belajar matematika siswa, berada pada tabel kriteria tingkat korelasi dan kekuatan hubungan yang sangat kuat yaitu antara 0,80-0,100. Sedangkan arah hubungan adalah positif karena nilai $\mathrm{r}$ positif, yang artinya semakin tinggi rasa percaya diri dan kebiasaan belajar yang dimiliki oleh siswa maka semakin tinggi pula hasil belajarnya.

Kemudian berdasarkan perhitungan di atas diperoleh uji signifikan sig $=0,000<=0,05$, sehingga keputusannya Ho ditolak. Artinya terdapat hubungan yang positif dan signifikan antara rasa percaya diri dan kebiasaan belajar secara bersama-sama dengan hasil belajar matematika siswa kelas VIII SMP Negeri 16 Batam Tahun Pelajaran 2016/2017.

Sedangkan untuk menyatakan besar kecilnya sumbangan yang diberikan oleh variabel $\mathrm{X}_{1}$ dan $\mathrm{X}_{2}$ terhadap variabel $\mathrm{Y}$ dapat dilihat dari perhitungan berikut:

Artinya besar sumbangan rasa percaya diri dan kebiasaan belajar dengan hasil belajar matematika siswa kelas IX SMP Negeri 16 Batam sebesar 66,42\%. Sisanya 33,58\% ditentukan oleh faktor lain yang tidak diteliti dalam penelitian ini. 
Hubungan yang positif dan signifikan antara rasa percaya diri dengan hasil belajar matematika dapat disebabkan oleh beberapa hal yang sesuai dengan indikator rasa percaya diri, diantaranya siswa mampu bersikap optimis, memiliki kemampuan menghadapi masalah, mandiri dan bertanggung jawab terhadap keputusan dan tindakannya. Siswa yang memiliki rasa percaya diri yang baik merasa senang dan mampu dalam mengerjakan soal matematika, selalu bersyukur dengan kemamampuanya sehingga mempunyai prestasi yang baik, serta berani bertanggung jawab terhadap setiap keputusan dan tindakannya. Sedangkan siswa yang kurang memiliki percaya diri terlihat dengan kurangnya keyakinan dan memilki perasaan ragu-ragu dalam menyelesaikan persoalan matematika, mudah menyerah dengan hasil pekerjannya serta tidak mampu bertanggung jawab terhadap keputusan dan tindakannya. Hal ini sejalan dengan hasil penelitian dari Arly (2014) yang menyatakan bahwa terdapat hubungan yang positif dan signifikan antara rasa percaya diri dengan hasil belajar matematika siswa kelas VII SMP N 22 Batam.

Hubungan yang positif dan signifikan antara kebiasaan belajar dengan hasil belajar ini dapat disebabkan beberapa hal yang sesuai dengan indikator dari kebiasaan belajar. Beberapa hal tersebut diantaranya adalah siswa mampu membuat persiapan belajar yang baik, mampu mengikuti pelajaran dengan menyimak dan bertanya, memiliki cara yang baik dalam belajar kelompok maupun individu, mempunyai jadwa belajar yang teratur, mempunyai kesadaran diri untuk membaca dan membuat catatan serta mengulang pelajaran tanpa adanya perintah terlebih dahulu, dan mampu mengalokasikan waktu yang baik untk belajar. Sedangkan siswa yang memiliki kebiasaan belajar kurang baik kebiasaan terlihat dari tindakannya yang tidak mampu membuat persiapan belajar yang baik, cenderung merasa senang jika pelajaran telah usai, belajar kelompok hanya untuk bersenang-senang, malas untuk membuat catatan ditandai dengan mencatat hal-hal yang dianggap penting, tidak sempat dalam membuat jadwal serta lebih banyak meluangkan waktunya untuk bersantai dibandingkan belajar. Hal ini sejalan dengan hasil penelitian Aditya (2013) yang menunjukkan adanya pengaruh yang signifikan antara kebiasaan belajar matematika dengan prestasi belajar matematika.

\section{KESIMPULAN}

Berdasarkan hasil penelitian dan pembahasan yang telah dilakukan, maka diperoleh kesimpulan sebagai berikut:

1. Terdapat hubungan yang positif dan signifikan antara rasa percaya diri dengan hasil belajar matematika siswa kelas IX SMP Negeri 16 Batam diperoleh dari hasil analisis korelasi Product Moment sebesar 0,523 yang tergolong dalam kategori cukup kuat.

2. Terdapat hubungan yang positif dan signifikan antara kebiasaan belajar dengan hasil belajar matematika siswa kelas IX SMP Negeri 16 Batam diperoleh dari hasil analisis korelasi Product Moment sebesar 0,780 yang tergolong dalam kategori kuat.

3. Terdapat hubungan yang positif dan signifikan antara rasa percaya diri dan kebiasaan belajar secara bersama-sama dengan hasil belajar matematika siswa kelas IX SMP Negeri 16 Batam diperoleh dari hasil analisis korelasi sebesar 0,815 yang tergolong dalam kategori sangat kuat. 


\section{DAFTAR PUSTAKA}

Aditya Satya Nugraha. (2013). Pengaruh Antara Motivasi, Kecerdasan, dan Kebiasaan Belajar Terhadap Prestasi belajar Matematika Siswa Semester 2 Kelas VIII B SMP Negeri 2 Ngadirojo”. Naskah Publikasi, Universitas Muhammadiyah Surakarta.

Arly Asena Syarif. (2014). "Hubungan Antara Self Confidence dan Personality dengan Hasil Belajar Matematika Siswa Kelas VII SMP Negeri 22 Batam Tahun Pelajaran 2013/2014”. Skripsi, Universitas Riau Kepulauan, Batam.

Aunurrahman. (2014). Belajar dan Pembelajaran. Bandung: Alfabeta.

Djaali. (2014). Psikologi Pendidikan. Jakarta: Bumi Aksara.

Nana Sudjana. (2012). Penilaian Hasil Proses Belajar Mengajar. Bandung: PT Remaja Rosdakarya.

Siregar, Syofian. (2015). Statistik Parametrik untuk Penelitian Kuantitatif. Jakarta: Bumi Aksara.

Sugiyono. (2013). Metode Penelitian Pendidikan Pendekatan Kuantitatif Kualitatif dan R\&D. Jakarta: Alfabeta.

Turmudi. (2009). Taktik dan Strategi Pembelajaran Matemamtika. Jakarta: PT Leuser Citra Pustaka. 
